\title{
PEMIDANAAN TERHADAP ANAK SEBAGAI PELAKU TINDAK PIDANA STUDI KASUS PERKARA PIDANA NOMOR 07/PID-SUS-ANAK/2017/PN.PDG*
}

\author{
Dewi Elvi Susanti \\ Fakultas Hukum, Universitas Andalas \\ Jalan Gajah Mada Nomor 22 Kecamatan Nanggalo Kota Padang, \\ e-mail: dewielvisusanti@gmail.com
}

\begin{abstract}
This study illustrates the basis and consideration of public prosecutors and judges in convicting children as perpetrators of crimes in a letter of claim and decision. There were two issues that would be examined, namely: a) What is the basis and consideration of the Public Prosecutor to file a complaint against the Child as a criminal in a case Number: 07/Pid.SusAnak/2017/Pn.Pdg, $b$ ) What is the basis and consideration of the Judge in making a decision on the Child as a criminal offender in the decision Number: 07/Pid.Sus-Anak/2017/Pn.Pdg, To discuss this problem a normative juridical method is used. From the results of the research obtained answers, a) the basis of the public prosecutor to file a claim against a child is Law Number 3 of 1997 concerning the Juvenile Court and Law Number 11 of 2012 concerning the Juvenile Justice System, and several Circular of the Indonesian Attorney General, while prosecutor's consideration General filed a claim in court No. 07/Pid.Sus-Anak/2017/Pn.Pdg was the fulfillment of the elements of the article being charged, things that incriminate and alleviate children's actions, the condition of parents of children, recommendations of correctional facilities (Bapas), paying attention to the interests of the community, victims and perpetrator; $b$ ) the basis of the judge in making a decision in case No. 07/Pid.Sus-Anak/2017/Pn.Pdg was Law Number 11 of 2012 concerning the Criminal Justice System of Children and was Law Number 3 of 1997 concerning Juvenile Courts. There were 2 (two) considerations the judge handed down the decision in case No. 07/Pid.SusAnak/2017/Pn.Pdg are juridical considerations and non-juridical considerations.
\end{abstract}

Keywords: Child; Actor; Crime; Penalty.

\begin{abstract}
Abstrak
Kajian ini menganalisis dasar dan pertimbangan jaksa penunut umum dan hakim dalam mempidana anak sebagai pelaku tindak pidana dalam surat tuntutan dan putusan. Ada dua hal permasalahan yang akan dikaji yaitu: pertama Apa dasar dan pertimbangan Penuntut Umum mengajukan tuntutan terhadap Anak sebagai pelaku tindak pidana dalam perkara Nomor: 07/Pid.Sus-Anak/2017/Pn.Pdg, kedua apa dasar dan pertimbangan Hakim dalam menjatuhkan putusan terhadap Anak sebagai pelaku tindak pidana dalam putusan Nomor: 07/Pid.SusAnak/2017/Pn.Pdg, Untuk membahas masalah tersebut digunakanlah metode yuridis normatif. Dari hasil penelitian diperoleh jawaban, pertama dasar penuntut umum mengajukan tuntutan terhadap anak adalah Undang-undang Nomor 3 Tahun 1997 tentang Pengadilan Anak dan Undang-undang Nomor 11 Tahun 2012 tentang Sistem Peradilan Anak, dan beberapa Surat Edaran Jaksa Agung RI, sedangkan pertimbangan Penuntut Umum mengajukan tuntutan dalam perkara No. 07/Pid.SusAnak/2017/Pn.Pdg adalah terpenuhinya unsur-unsur dari pasal yang didakwakan, hal yang memberatkan dan meringankan perbuatan anak, keadaan orang tua anak, rekomendasi dari balai pemasyarakatan (Bapas), memperhatikan kepentingan masyarakat, korban dan pelaku kejahatan; kedua dasar hakim dalam menjatuhkan putusan terhadap dalam perkara No. O7/Pid.SusAnak/2017/Pn.Pdg adalah Undang-undang Nomor 11 tahun 2012 tentang Sistem Peradilan Pidana Anak dan adalah Undang-undang Nomor 3 Tahun 1997 tentang Pengadilan Anak. Ada 2 (dua)
\end{abstract}

\footnotetext{
* Naskah diterima: 18 Oktober 2018, direvisi: 11 Maret 2018, disetujui untuk terbit: 19 Maret 2019 Doi: $\underline{10.3376 / j c h . v 4 i 2.103}$
} 
pertimbangan hakim menjatuhkan putusan dalam perkara No. 07/Pid.Sus-Anak/2017/Pn.Pdg adalah pertimbangan yuridis dan pertimbangan non yuridis.

Kata Kunci: Anak; Pelaku; Tindak Pidana; Pemidanaan.

\section{PENDAHULUAN}

Anak bukanlah objek untuk dihukum melainkan harus diberikan bimbingan dan pembinaan, sehingga bisa tumbuh dan berkembang sebagai anak normal yang sehat dan cerdas seutuhnya. Anak adalah anugerah Allah Yang Maha Kuasa sebagai calon generasi penerus bangsa yang masih dalam masa perkembangan fisik dan mental. Terkadang Anak mengalami situasi sulit yang membuatnya melakukan tindakan yang melanggar hukum. Walaupun demikian, anak yang melanggar hukum tidaklah layak untuk dihukum apalagi kemudian dimasukkan dalam penjara (M. Nasir Djamil, 2015: 1)

Dilanjutkan dalam pasal 1 ayat (3) Undang-undang Nomor 11 Tahun 2012 tentang Sistem Peradilan Anak, yang berkonflik dengan hukum yang selanjutnya disebut anak adalah anak yang telah berumur 12 (dua belas) tahun, tetapi belum berumur 18 (delapan belas) tahun yang diduga melakukan tindak pidana.

Undang-Undang Dasar 1945 Pasal 27 ayat (1) menyatakan bahwa segala warga negara bersamaan kedudukannya di dalam hukum dan pemerintah dan wajib menjunjung hukum dan pemerintah itu dan tidak ada kecualinya. Namun terhadap seorang anak sebagai pelaku tindak pidana berlaku perlindungan khusus dengan tujuan melindungi kepentingan anak dan masa depan anak.
Di jelaskan juga dalam pasal 1 ayat (2) Undang-undang Nomor 23 Tahun 2002 tentang Perlindungan anak, bahwa perlindungan anak adalah segala kegiatan untuk menjamin dan melindungi anak dan hak-haknya agar dapat hidup, tumbuh berkembang dan berpartisipasi secara optimal sesuai dengan harkat dan martabat kemanusiaan, serta mendapat perlindungan dari kekerasan dan diskriminasi.

Tindak pidana yang dilakukan anak selalu menuai kritikan terhadap para penegak hukum yang oleh banyak kalangan dinilai tidak mengindahkan tata cara penanganan terhadap anak yang bermasalah dengan hukum, dan ada kesan kerap kali mereka diperlakukan sebagai orang dewasa dalam bentuk kecil yang melakukan tindak pidana. Disamping itu sistim pemidanaan yang sampai sekarang terkadang masih memperlakukan anakanak yang terlibat sebagai pelaku tindak pidana itu seperti pelaku tindak pidana yang dilakukan oleh orang dewasa. Anak ditempatkan dalam posisi sebagai seorang pelaku kejahatan yang patut untuk mendapatkan hukum yang sama dengan orang dewasa.

Pemidanaan saat ini lebih berorientasi kepada individu pelaku atau biasa disebut dengan pertanggung jawaban individual/ personal (Individual responsibility) dimana pelaku dipandang sebagai individu yang mampu untuk bertanggung 
Dewi Elvi Susanti: Pemidanaan Terhadap Anak Sebagai Pelaku Tindak Pidana...

jawab penuh terhadap perbuatan yang dilakukannya. Sedangkan anak merupakan individu yang belum dapat menyadari secara penuh atas tindakan/ perbuatan yang dilakukannya, hal ini disebabkan karena anak merupakan individu yang belum matang dalam berpikir (Mardjono Reksodiputro, 1997: 43).

Untuk mencermati hukuman yang cocok untuk anak yang melakukan tindak pidana muncullah berbagai pandangan para ahli, diantaranya menurut Herbert L. Packer, ada dua pandangan konseptual yang masing-masing mempunyai implikasi moral yang berbeda satu sama lain, yakni pandangan retributif (retributive view) dan pandangan utilitarian (utilitarian view). Pandangan retributif mengandaikan pemidanaan sebagai ganjaran negatif terhadap perilaku menyimpang yang dilakukan oleh warga masyarakat sehingga pandangan ini melihat pemidanaan hanya sebagai pembalasan terhadap kesalahan yang dilakukan atas dasar tanggung jawab moralnya masing-masing. Pandangan ini dikatakan bersifat melihat ke belakang (backward-looking). Pandangan utilitarian melihat pemidanaan dari segi manfaat atau kegunaannya dimana yang dilihat adalah situasi atau keadaan yang ingin dihasilkan dengan dijatuhkannya pidana itu. Di satu pihak, pemidanaan dimaksudkan untuk memperbaiki sikap atau tingkah laku terpidana dan di pihak lain pemidanaan itu juga dimaksudkan untuk mencegah orang lain dari kemungkinan melakukan perbuatan yang serupa. Pandangan ini dikatakan berorientasi ke depan (forward-looking) dan sekaligus mempunyai sifat pencegahan (detterence) (Zainal Abidin, 2005: 10).

Muladi di dalam disertasinya yang berjudul "Lembaga Pidana Bersyarat Sebagai Faktor yang Mempengaruhi Proses Hukum Pidana yang Berperikemanusiaan" memperkenalkan teori tujuan pemidanaan yang integratif (Kemanusiaan dalam Sistem Pancasila). Dilandasi oleh asumsi dasar, bahwa tindak pidana merupakan gangguan terhadap keseimbangan, keselarasan dan keserasian dalam kehidupan masyarakat yang mengakibatkan kerusakan individu ataupun masyarakat. Dengan demikian maka tujuan pemidanaan adalah untuk memperbaiki kerusakan individu dan masyarakat yang diakibatkan oleh tindak pidana tersebut. Hal ini terdiri dari seperangkat tujuan pemidanaan yang harus dipenuhi, dengan catatan, bahwa tujuan manakah yang merupakan titik berat sifatnya kasuistis (Dwidja Priyatno, 2009: 28).

Menurut Muladi (Muladi, 1995: 2), tujuan pemidanaan dijadikan patokan dalam rangka menunjang bekerjanya sistem peradilan pidana dimaksudkan untuk menciptakan sinkronisasi yang bersifat fisik, meliputi sinkronisasi struktural (structural synchronization), sinkronisasi substansial (substansial synchronization) dan dapat pula bersifat sinkronisasi kultural (cultural synchronization). Dalam hal sinkronisasi kultural, keserempakan dan keselarasan 
dituntut dalam mekanisme administrasi peradilan pidana (the administration of justice) dalam rangka hubungan antar Dasar dari pada adanya perbuatan pidana adalah asas legaliteit, yaitu asas yang menentukan bahwa sesuatu perbuatan adalah dilarang dan diancam dengan pidana barang siapa yang melakukannya, sedangkan dasar dari pada dipidanannya sipembuat adalah asas "tidak dipidana jika tidak ada kesalahan”. Dapat pula dikatakan orang tidak mungkin dipertanggung jawabkan dan dijatuhi pidana kalau tidak melakukan perbuatan pidana. Tetapi meskipun dia melakukan perbuatan pidana, tidaklah selalu dia dapat dipidana, jika yang melakukan pidana adalah orang yang sakit jiwa. Di dalam proses peradilan pidana terhadap anak masih saja memperlakukan tersangka anak sama dengan tersangka dewasa, malah terjadi adanya pelanggaran HAM. Padahal ada perbedaan penanganan di dalam proses peradilan pidana. Masalah proses peradilan pidana terhadap anak diatur di dalam UndangUndang Repsublik Indonesia No. 11 Tahun 2012 tentang Sistem Peradilan Pidana Anak. Mengapa masalah dalam proses peradilan anak masih terjadi pelanggaran HAM atau salah dalam menerapkan hukum?

Sejak berlakunya Undang-undang Nomor 11 tahun 2012 tentang Sistem Peradilan Pidana Anak, Pengadilan Negeri Padang dalam hal menangani perkara Anak selaku pelaku tindak pidana telah memutus perkara dengan bentuk tindak pidana yang beragam mulai dari perkara tindak pidana pencurian dengan kekerasan, tindak pidana pengrusakkan, persetubuhan terhadap Anak dan penganiayaan, dengan bentuk putusan pidana yang sangat memperhatikan kepentingan Anak pelaku dimana Pengadilan Negeri Padang lebih banyak mengeluarkan putusan dalam bentuk latihan kerja di LPKS (lembaga penyelenggara kesejahteraan sosial) untuk anak pelaku yang orang tuanya masih sanggup membina anaknya dan menempatkan anak di LPKA (lembaga pembinaan khusus Anak) untuk Anak yang orang tuanya dinilai tidak dapat membina Anaknya kembali oleh Hakim Anak.

Pasal 59 Undang-undang Nomor 11 tahun 2012 menyatakan bahwa pemerintah dan lembaga Negara lainnya memiliki kewajiban dan tanggung jawab memberikan perlindungan khusus kepada Anak yang berhadapan dengan hukum baik anak yang berkonflik dengan hukum maupun anak sebagai korban tindak pidana. Pasal 40 ayat (1) Konvensi Hak Anak 1990 memberikan batasan yang dimaksud dengan Anak yang berkonflik dengan hukum yaitu Anak yang disangka, dituduh, atau diakui telah melanggar Undang-undang Hukum Pidana, dimana Konvensi Hak Anak memiliki perspektif terhadap anak yang berkonflik dengan hukum dikategorikan dalam situasi yang khusus, hal ini seiring dengan UNICEF yang menyebut anak dalam situasi khusus sebagai Children in especially difficult circum stances (CEDS) hal ini dikarenakan tidak terpenuhinya 
Dewi Elvi Susanti: Pemidanaan Terhadap Anak Sebagai Pelaku Tindak Pidana...

kebutuhan-kebutuhan, rentan mengalami kekerasan, berada di luar lingkungan keluarga (dalam lingkup institusi Negara), membutuhkan perlindungan, keamanan terhadap diri, serta proteksi berupa regulasi khusus, dimana hal tersebut tidak dapat terpenuhi karena anak tidak mendapatkan perlindungan dan perawatan dari orang dewasa dimana anak berada. (Wiwik Afifah, 2014: 56)

Dalam memberikan perlindungan terhadap Anak yang berkonflik dengan hukum haruslah berdasarkan pada azasazas yang diatur pada pasal 2 Undangundang Nomor 11 tahun 2012 tentang Sistem Peradilan Pidana Anak antara lain: azas perlindungan, azas keadilan, azas nondiskriminasi, azas kepentingan terbaik bagi anak, azas penghargaan terhadap pendapat anak, azas kelangsungan hidup dan tumbuh kembang anak, azas pembinaan dan pembimbingan anak, azas proporsional, azas perampasan kemerdekaan dan pemidanaan sebagai upaya terakhir dan azas penghindaran. Undang-undang Nomor 11 tahun 2012 tentang Sistem Peradilan Pidana Anak mengedepankan penyelesaian konflik hukum yang melibatkan anak sebagai pelaku pada pemulihan dan penggantian kerugian yang dialami korban dari pada penghukuman anak sebagai pelaku, hal ini lebih dikenal dengan konsep Restoratif Justice. Hal ini dilatar belakangi oleh konsep pemikiran yang menyatakan bahwa proses penyelesaian perkara pidana yang melibatkan Anak sebagai pelaku tidaklah semata-mata bertujuan untuk menghukum Anak tapi juga bertujuan untuk mendidik Anak dimana tujuan utama dari proses penyelesaian perkara pidana anak yaitu mengembalikan dan memulihkan kondisi seperti sebelum terjadinya tindak pidana, dengan adanya konsep Restoratif Justice yang merupakan penyelesaian perkara pidana Anak diluar peradilan pidana memberikan solusi yang komprehensif dan efektif, dimana keadilan yang diberikan dengan memberikan dukungan kepada korban dan masyarakat supaya Anak pelaku bertanggung jawab dan tidak didasarkan pada pembalasan yang setimpal pada pelaku Anak baik secara phisikis, fisik atau hukuman. (Olvina Kartika Mamentu, 2015: 146).

Pasal 7 ayat (1) Undang-undang Nomor 11 tahun 2012 tentang Sistem Peradilan Pidana Anak menyatakan bahwa wajib dilakukan diversi dalam semua tahap pemeriksaan baik tingkat penyidikan, penuntutan dan pemeriksaan Anak di Pengadilan Negeri. Bahwa dasar bagi Penyidik dan Penuntut Umum dalam melakukan diversi hanyalah Undangundang Nomor 11 tahun 2012 tentang Sistem Peradilan Pidana Anak dan Peraturan Pelaksana Nomor 65 tahun 2015, dimana kedua peraturan hukum tersebut tidak memberikan penjelasan dan petunjuk teknis tentang bagaimana Diversi itu dilakukan, demikian juga Mahkamah Agung yang telah mengeluarkan Peraturan Mahkamah Agung Nomor 4 tahun 2014 tentang Pedoman Pelaksanaan Diversi dalam Sistem Peradilan Pidana Anak dengan mengingat ketentuan Pasal 15 UU Nomor 
11 tahun 2012 tentang Sistem Peradilan Pidana Anak yang didasarkan pada tujuan untuk mengisi kekosongan hukum acara tentang pelaksanaan diversi, tata cara, dan koordinasi pelaksanaan diversi dimana PERMA tersebut hanya berlaku intern bagi Institusi Mahkamah Agung sendiri dalam hal ini yaitu Pengadilan Negeri juga tidak memberikan penjelasan tentang penerapan pasal 79 sehingga penerapan pasal tersebut hanyalah berdasarkan penafsiran masing-masing pihak penegak hukum.

Proses Diversi dilakukan melalui musyawarah antara para pihak yang terlibat yang wajib memperhatikan kepentingan korban, kesejahteraan dan rasa tanggung jawab anak, menghindari stigma negative, menghindari pembalasan, keharmonisan masyarakat serta kepatutan, kesusilaan dan ketertiban, sehingga dengan diperolehnya kesepakatan dari para pihak yang terlibat maka stigma negative dari Anak pelaku tindak pidana dan pembalasan dapat dihindari, dimana penyelesaian perkara pidana Anak berorientasi pada Keadilan Restoratif (Adi Hardiyanto Wicaksono, Pujiyono, 2015: 20).

Pada bulan Juni 2016 sejumlah siswa SMP Sahara Kota Padang merayakan kelulusannya dengan konvoi sepeda motor di jalan-jalan Kota Padang, tanpa sebab yang jelas salah satu Anak yaitu Fauzan Arsi Putra yang dibonceng oleh temannya melayangkan Gear yang telah diikatkan ke sabuk dengan serampangan saat melewati sejumlah siswa dari SMPN 12 Kota Padang yang kebetulan sedang berjalan di trotoar sehingga Gear tersebut mengenai muka anak Gion Salendra yang mengakibatkan luka parah pada matanya. Orang tua dari Gio Salendra merasa tidak senang karena anaknya menderita luka parah kemudian melaporkan Fauzan Arsi Putra ke Polresta Padang sehingga Fauzan Arsi Putra diproses secara hukum dimana saat itu Fauzan Arsi Putra berumur 17 (tujuh belas) tahun, dimana pihak Polresta Padang memproses Anak tersebut sesuai dengan Undang-undang Nomor 11 tahun 2012 tentang Sistem Peradilan Anak. Komitmen anak wajib dilindungi agar tidak menjadi korban dan menderita kerugian secara mental, fisik dan sosial yang disebabkan tindakan kebijakan siapa saja, yang aktif ataupun pasif, baik itu dari diri sendiri, individu atau kelompok, organisasi swasta maupun pemerintah baik secara langsung ataupun tidak langsung. Disamping itu, khusus bagi anak yang menjadi pelaku tindak pidana, maka demi pertumbuhan dan perkembangan mental anak perlu ditentukan pembedaan perlakuan di dalam hukum acara dan ancaman pidananya dengan maksud untuk lebih mengayomi anak tersebut agar dapat menyongsong masa depannya yang masih panjang dan memberi kesempatan kepada anak agar melalui pembinaan akan memperoleh jati dirinya untuk menjadi manusia yang mandiri, bertanggung jawab dan berguna bagi diri, keluarga, dan masyarakat.

\section{METODE PENELITIAN}

Penelitian ini menggunakan pendekatan masalah secara normatif, yakni pendekatan yang beranjak dari 
Dewi Elvi Susanti: Pemidanaan Terhadap Anak Sebagai Pelaku Tindak Pidana...

peraturan perundang-undangan sebagai bahan hukum utama dengan cara menelaah teori-terori, konsep-konsep, azas-azas hukum yang bersangkutan dengan masalah hukum yang berhubungan dengan penelitian ini, sehingga penulis dapat menyusun pendapat hukum yang diperoleh. Penyusunan bahan hukum bertujuan untuk menyeleksi bahan hukum yang relevan dengan penelitian ini. Klasifikasi bahan hukum bertujuan untuk memisahkan antara bahan hukum yang diperoleh dari penelitian pusaka (library research) Melalui penelitian yuridis normatif dapat terlihat apa yang menjadi dasar dan pertimbangan Penuntut Umum dalam mengajukan tuntutan terhadap anak sebagai pelaku tindak pidana dan apa yang menjadi dasar dan pertimbangan Hakim dalam menjatuhkan pidana terhadap anak sebagai pelaku tindak pidana.

\section{HASIL DAN PEMBAHASAN}

A. Dasar dan pertimbangan Penuntut Umum mengajukan tuntutan terhadap Anak sebagai Pelaku Tindak Pidana dalam Kasus Putusan Perkara Nomor

\section{7/Pid.Sus-Anak/2017/PN.Pdg}

Mempelajari pertimbangan Penuntut Umum dalam mengajukan tuntutan terhadap Anak Fauzan Arsi Putra pgl. Ojan bin Abadi tersebut dihubungkan dengan konsep Restoratif Justice yang ada dalam Undang-undang Nomor 11 tahun 2012 yang dilaksanakan dengan cara Diversi (pengalihan), dimana Diversi dilakukan karena dilatar belakangi keinginan menghindarkan Anak pelaku dari efek negatif dalam penyelesaian perkara pidananya. Pelaksanaan Diversi oleh aparat penegak hukum didasari oleh kewenanganyang disebut dengan discretion atau diskresi. Dalam hubungan dengan discretion power dalam proses perkara pidana, kata diskresi sering dihubungkan dengan kewenangan polisi saja sementara kewenangan serupa dihubungkan dengan jaksa dikenal sebagai hak mendeponir atau mengalihkan perkara yang lazim dikenal dengan oportunitas. Jaksa menggunakan opurtunitasnya atas dasar kewenangan diskresi yang dimilikinya dalam memutuskan apakah suatu perkara diteruskan untuk dilakukan penuntutan atau tidak. Dalam penuntutan, dikenal azas yang disebut dengan azas legalitas dan oputunitas (legaliteit en het opportuniteits beginsel). Menurut azas legalitas, Penuntut Umum wajib menuntut suatu tindak pidana, artinya Jaksa harus melanjutkan penuntutan perkara yang cukup bukti, sedangkan menurut azas oportunitas, Jaksa berwenang menuntut atau tidak menuntut suatu perkara ke Pengadilan, baik denga syarat maupu tanpa syarat. Jadi dalam hal ini, Penuntut Umum tidak wajib menuntut seseorang yang melakukan tindak pidana jika menurut pertimbangannya akan merugikan kepentingan umum.

Dalam hal perkara atas nama Anak Fauzan Arsi Putra pgl. Ojan bin Abadi Penuntut Umum telah melakukan penyelesaian pidana secara Restoratif Justice melalui tindakan Diversi dimana 
Anak Fauzan Arsi Putra pgl. Ojan bin Abadi yang didampingi oleh orang tuanya, demikian juga Anak korban Gion Salendra Irari pgl. Gion yang didampingi oleh orang tuanya, yang dihadiri juga oleh Petugas Balai Pemasyarakatan dan Pekerja Sosial serta Penasihat Hukum Anak telah duduk bersama-sama dengan Penuntut Umum di ruang Diversi mencari penyelesaian di luar persidangan, namun dikarenakan orang tua dari Gion Salendra pgl. Gion tidak bisa memaafkan dan menghendaki penyelesaian hukum dilanjutkan ke Peridangan maka Penuntut Umum melimpahkan perkara tersebut ke Pengadilan Negeri Padang pada tanggal 23 Juni 2016.

Selesai pemeriksaan sidang terhadap Anak selanjutnya Penuntut Umum berwenang mengajukan tuntutan Pidana guna membuktikan dakwaan yang didakwakan terhadap terdakwa (Requisitoir), dasar hukumnya Pasal 182 ayat (1) huruf a KUHAP. Dalam buku "Peristilahan hukum dalam praktek" (Kejaksaan Agung Republik Indonesia, 1985) memuat kata "Requisitoir" yaitu tuntutan hukuman jaksa penuntut umum pada pengadilan negeri setelah pemeriksaan ditutup (Leden Marpaung, 1992: 300).

Surat tuntutan (requisitoir) yang baik adalah surat tuntutan yang mengandung fakta hukum tentang peristiwa pidana sehingga dapat diperoleh kesimpulan hukum tentang terbukti atau tidaknya tindak pidana yang didakwakan.
1. Dasar Penuntut Umum

Mengajukan Tuntutan Terhadap anak Sebagai Pelaku Tindak Pidana

Adapun yang menjadi dasar bagi Penuntut Umum dalam mengajukan tuntutan pidana kepada anak sebagai pelaku tindak pidana dalam Kasus Putusan Perkara No.07/Pid.SusAnak/2017/PN.Pdg mengacu kepada peraturan perundang-undangan, diantaranya:

a. Undang-Undang Nomor 3 Tahun 1997 tentang Pengadilan Anak;

b. Undang-Undang Nomor 11 Tahun 2012 tentang Sistem Peradilan Anak;

c. Surat Edaran Jaksa Agung RI Nomor: SE-001/JA/4/1995 tanggal 27 April 1995 tentang Pedoman Tuntutan Pidana;

d. Surat Edaran Jaksa Agung RI Nomor: SE-02/JA/6/1989 tanggal 10 Juli 1989 tentang Penuntutan Terhadap Ana;

e. Surat Edaran Jaksa Agung Muda Tindak Pidana Umum Nomor: B532/E11/1995 tanggal 9 November 1995 tentang petunjuk tekhnis tentang penuntutan terhadap anak;

f. Surat Edaran Jaksa Agung Muda Tindak Pidana Umum Nomor: B741/E/Epo.1/XII/1998 tanggal 15 Desember 1998 dan Nomor: B129/E.3/Epo.1/2/1999 Perihal Pelaksanaan Undang-Undang Nomor: 3 Tahun 1997 tentang Pengadilan Anak;

g. Surat Edaran Jaksa Agung Muda Tindak Pidana Umum No. B- 
Dewi Elvi Susanti: Pemidanaan Terhadap Anak Sebagai Pelaku Tindak Pidana...

363/E/EJP/02/2010 tanggal 25

Februari 2010 tentang Petunjuk

Teknis Penanganan Anak Yang

Berhadapan Dengan Hukum;

Namun dari aturan-aturan yang menjadi acuan Penuntut Umum dalam mengajukan tuntutan pidana terdapat hal yang paling utama dan yang menjadi perhatian penuntut umum yaitu memberikan perlindungan kepada anak dan tidak semata-mata melihat perbuatan jahat yang telah dilakukan oleh anak.

2. Pertimbangan Penuntut Umum dalam Mengajukan Tuntutan Terhadap anak Sebagai Pelaku Tindak Pidana dalam Kasus Putusan Perkara Nomor 07/Pid.Sus-Anak/2017/PN.Pdg

Dalam Perkara Nomor 07/Pid.SusAnak/2017/PN.Pdg, Penuntut Umum memiliki beberapa pertimbangan dalam mengajukan tuntutan berupa pidana penjara 1 (satu) tahun dan 6 (enam) bulan terhadap Anak Fauzan Arsi Putra pgl. Ojan bin Abadi diantaranya sebagai berikut:

\section{a) Terpenuhinya Unsur-Unsur Dari Pasal Yang Didakwakan Dalam Surat Dakwaan}

Dalam Perkara Nomor 07/Pid.SusAnak/2017/PN.Pdg, Penuntut umum dalam mendakwa terdakwa dengan surat dakwaan yang disusun secara Alternatif Subsidaritas yaitu Dakwaan Kesatu, Primair: Pasal 351 ayat (2) KUHP jo Undang-undang Nomor 11 tahun 2012 tentang Sistem Peradilan Pidana Anak.
Subsidiair: Pasal 351 ayat (1) KUHP jo Undang-undang Nomor 11 tahun 2012 tentang Sistem Peradilan Pidana Anak; atau Dakwaan Kedua: Pasal $76 \mathrm{C}$ jo. Pasal 80 Undang-undang Nomor 35 tahun 2014 tentang Perubahan atas Undangundang Nomor 23 tahun 2002 tentang Perlindungan Anak jo Undang-undang Nomor 11 tahun 2012 tentang Sistem Peradilan Pidana Anak. Surat dakwaan tersebut memiliki peranan yang penting dalam melakukan pemeriksaan dan pembuktian di pengadilan. Hal ini sejalan dengan pernyataan menurut Yahya Harahap (2003:390) bahwa :

Seorang terdakwa yang dihadapkan ke sidang pengadilan hanya dapat dijatuhi hukuman karena telah terbukti melakukan tindak pidana seperti yang disebutkan atau yang dinyatakan jaksa dalam surat dakwaan. Oleh karena itu pendekatan pemeriksaan persidangan harus bertitik tolak dan diarahkan kepada usaha membuktikan tindak pidana yang dirumuskan dalam surat dakwaan.

Berdasarkan proses pemeriksaan di pengadilan dalam perkara Nomor 07/Pid.Sus-Anak/2017/PN.Pdg dengan memperhatikan ketentuan pasal 184 KUHAP didapat alat bukti yang sah terdiri dari keterangan saksi, keterangan ahli, surat, petunjuk, keterangan terdakwa sehingga Penuntut Umum berkeyakinan Anak terbukti bersalah sesuai dengan Dakwaan Primair melanggar Pasal 351 ayat (2) KUHP yaitu Penganiayaan yang mengakibatkan luka berat. 
b) Adanya Hal Yang Memberatkan Dan hal Yang Meringankan.

Penuntut Umum dalam mengajukan tuntutan terhadap Anak juga mempertimbangkan hal-hal yang memberatkan dan hal-hal yang meringankan perbuatan Anak, dimana hal tersebut menjadi pertimbangan untuk mewujudkan suatu keadilan bagi Anak sebagai pelaku kejahatan, anak selaku korban serta melindungi masyarakat. Adapun hal yang memberatkan dalam perkara Nomor 07/Pid.SusAnak/2017/PN.Pdg adalah perbuatan Anak selaku pelaku kejahatan telah meresahkan masyarakat, perbuatan Anak menimbulkan trauma, cedera fisik dan rasa takut yang dirasakan korban. Sedangkan hal yang meringankan dalam perkara Nomor 07/Pid.SusAnak/2017/PN.Pdg anak menunjukan sikap yang baik selama di persidangan, dan terdakwa belum pernah dihukum atau tidak sebelumnya.

\section{c) Orang tua anak dan keadaannya di ruang lingkup keluarga.}

Penuntut Umum menuntut Anak dengan pidana sebagai pelaku tindak pidana terungkap fakta bahwa Anak sebagai pelaku sering kali tidak mendapatkan kasih sayang dan perhatian yang cukup dari orang tuanya yang disebabkan oleh berbagi faktor dan yang paling sering dijumpai yaitu faktor ekonomi, dimana orang tua sibuk bekerja di luar untuk memcari uang sehingga orang tua tidak lagi memperhatikan dan dapat mendidik anak sebagaimana mestinya. Hal tersebut juga terjadi dalam perkara Nomor 07/Pid.SusAnak/2017/PN.Pdg.

\section{d) Rekomendasi dari Balai Pemasyarakatan (Bapas)}

Hasil penelitian Balai Pemasyarakatan (Bapas) merupakan andalan Penuntut Umum dalam mengajukan tuntutan pidana terhadap anak sebagai pelaku dimana Balai Pemasyarakatan (Bapas) dalam sistem peradilan anak yang memang mempunyai tugas melaksanakan pembimbing dan mendampingi anak dalam proses peradilan anak dan hal ini diatur dalam Undang-undang No. 12 Tahun 1995 tentang Pemasyarakatan. Di dalam Pasal 1 angka 4 disebutkan Balai Pemasyarakat yang selanjutnya disebut Bapas adalah pranata untuk melaksanakan bimbingan Klien Pemasyarakatan. Klien Pemasyarakatan yang selanjutnya disebut Klien adalah seseorang yang berada dalam bimbingan Bapas (Pasal 1 angka 9).

\section{e) Kepentingan Masyarakat}

Penuntut Umum mengajukan tuntutan berupa pidana penjara selama 1 (satu) tahun dan 6 (enam) bulan terhadap anak Fauzan Arsi Putra pgl. Ojan bin Abadi antara lain selain mempertimbangkan keamanan masyarakat, Penuntut Umum juga mempertimbangkan bahwa perbuatan Anak Fauzan Arsi Putra pgl. Ojan bin Abadi yang konvoi dengan motor ramairamai lalu tawuran tersebut sangat meresahkan masyarakat sehingga Penuntut Umum berpendapat bahwa 
Dewi Elvi Susanti: Pemidanaan Terhadap Anak Sebagai Pelaku Tindak Pidana...

pidana penjara selama 1 (satu) tahun dan 6 (enam) bulan tersebut akan menjadi peringatan dan efek jera bagi pelaku yang lain. Dalam hal ini pidana penjara yang diajukan terhadap Anak Pelaku dengan menempatkannya di Lembaga Pembinaan Khusus Anak berarti kebijaksanaan dalam perlakuan yang bersifat mengayomi masyarakat dari gangguan kejahatan sekaligus mengayomi para Pelaku Anak untuk dibina dan dibekali dengan ilmu, pendidikan dan keterampilan sebelum kembali ke masyarakat.

\section{f) Keadilan Korban}

Penuntut Umum mengajukan tuntutan berupa pidana penjara selama 1 (satu) tahun dan 6 (enam) bulan terhadap Anak pelaku sebagai sangsi yang tepat bagi perbuatan Anak Fauzan Arsi Putra pgl. Ojan bin Abadi, dimana Penuntut Umum mempertimbangkan bahwa perbuatan Anak Fauzan Arsi Putra pgl. Ojan bin Abadi telah menimbulkan penderitaan yang tetap bagi Anak Gion Salendra yang mengakibatkan Anak Gion Salendra kehilangan panca indranya, dan yang terpenting Penuntut Umum mengajukan tuntutan tersebut berharap dapat memberikan rasa keadilan bagi korban walaupun mungkin tidak sesuai yang diharapkan korban.

\section{g) Kepentingan Anak Pelaku}

Bahwa Penuntut Umum mengajukan tuntutan pidana penjara selama 1 (satu) tahun dan 6 (enam) bulan dengan mempertimbangkan dan memperhatikan keadaan Anak pelaku antara lain usia
Anak Pelaku dan keadaan psikisnya dengan memperhatikan penyebab Anak Pelaku melakukan kejahatan, apakah dikarenakan mendapat tekanan dari lingkungan atau orang lain, atau apakah pelaku Anak melakukan kejahatan dikarenakan emosi yang labil.

B. Dasar dan pertimbangan Hakim dalam menjatuhkan putusan terhadap Anak sebagai pelaku tindak pidana dalam putusan perkara Nomo :07/Pid.SusAnak/2017/Pn.Pdg

Sebelum membahas mengenai dasar dan pertimbangan Hakim dalam menjatuhkan putusan terhadap Anak sebagai pelaku tindak pidana dalam putusan Nomor: 07/Pid.SusAnak/2017/Pn.Pdg, Bab I Pasal Angka 11 KUHAP menyebutkan bahwa yang dimaksud dengan Putusan Hakim yaitu putusan pengadilan diartikan sebagai pernyataan hakim yang diucapkan dalam sidang pengadilan terbuka, yang dapat berupa pemidanaan atau bebas lepas dari segala tuntutan hukum dalam hal serta menurut cara yang diatur dalam undangundang ini.

\section{Dasar Hakim Dalam Menjatuhkan Putusan Terhadap Anak Sebagai Pelaku Tindak Pidana}

Adapun dasar hakim dalam menjatuhkan pidana dalam Perkara Nomor: $\quad$ 07/Pid.Sus-Anak/2017/Pn.Pdg adalah Undang-undang Nomor 11 tahun 2012 tentang Sistem Peradilan Pidana Anak dan Undang-undang Nomor 35 tahun 2014 tentang Perubahan atas Undang-undang Nomor 23 tahun 2004 
tentang Perlindungan Anak jo Undangundang Nomor 23 tahun 2004 tentang Perlindungan Anak.

2. Pertimbangan Hakim Dalam Menjatuhkan Putusan Terhadap Anak Sebagai Pelaku Tindak Pidana

Yang menjadi permasalahan menyangkut pemidanaan, yaitu jenis pidana, ukuran/ lamanya pidana yang dijatuhkan dan pelaksanaan pidana tersebut. Seiring dengan perkembangan ilmu pengetahuan tentang pidana dan pemidanaan, Hakim diberikan wewenang yang luas dalam mengeluarkan putusan berupa pidana untuk menanggulangi kejahatan, dan hal ini sesuai dengan pendapat Edi Djunedi yang menyatakan bahwa:

$\begin{array}{lrr}\text { "Kebebasan hakim } & \text { untuk } \\ \text { menjatuhkan } & \text { pidana } & \text { (judicial }\end{array}$ discreation insen-tencing) adalah berdasarkan pemikiran modern dalam ilmu kriminologi yang dipengaruhi ilmu psikologi dan ilmu sosial lainnya, yang menegaskan bahwa dalam menjatuhan pidana hakim haruslah mempergunakan asas individualisasi, sesuai dengan tindak pidana dan pelaku-nya...."(Gregorius Aryadi, 1994 : 30).

Dikarenakan hakim mempunyai kebebasan yang mandiri dalam mempertimbangkan berat ringannya sanksi pidana dalam putusan yang ditanganinya. Kebebasan hakim dalam menjatuhkan putusan pidana adalah mutlak dan tidak dicampuri oleh pihak lain. Hal ini untuk menjamin putusan pengadilan yang sifatnya objektif. Namun kebebasan hakim dalam menentukan berat ringannya sanksi pidana penjara tetap harus berpedoman pada batasan maksimum dan juga minimum dan kebebasan yang dimiliki harus berdasarkan pada rasa keadilan baik terhadap terdakwa dan korban maupun masyarakat serta bertanggung jawab terhadap Tuhan Yang Maha Esa.

Pertimbangan hakim merupakan salah satu aspek terpenting dalam menentukan terwujudnya nilai dari suatu putusan hakim yang mengandung keadilan (ex aequo et bono) dan mengandung kepastian hukum, di samping itu juga mengandung manfaat bagi para pihak yang bersangkutan sehingga pertimbangan hakim ini harus disikapi dengan teliti, baik, dan cermat. Apabila pertimbangan hakim tidak teliti, baik, dan cermat, maka putusan hakim yang berasal dari pertimbangan hakim tersebut akan dibatalkan oleh Pengadilan Tinggi Mahkamah Agung (Mukti Arto, 2004:140).

Hakim Anak pada Pengadilan Negeri Padang dalam Putusan No. 07/PID-SusAnak/2017/Pn.Pdg telah menjatuhkan putusan pidana bahwa Anak Fauzan Arsi Putra pgl. Ojan bin Abadi terbukti telah melakukan tindak pidana penganiayaan sebagaimana dinyatakan dalam surat dakwaan primer, pasal 351 ayat (2) KUHP dan menjatuhkan putusan terhadap Anak Fauzan Arsi Putra pgl. Ojan bin Abadi dengan pidana penjara selama 1 (satu) tahun di Lembaga Pembinaan Khusus Anak (LPKA) Tanjung Pati Kabupaten 50 Kota. 
Dewi Elvi Susanti: Pemidanaan Terhadap Anak Sebagai Pelaku Tindak Pidana...

\author{
Menilik secara saksama dalam \\ pertimbangan Majelis Hakim pada \\ putusan pidana No. 07/PID-Sus- \\ Anak/2017/Pn.Pdg menggunakan \\ pertimbangan yang bersifat yuridis dan \\ non yuridis.
}

\section{1) Pertimbangan Yuridis}

Adapun pertimbangan yang bersifat yuridis atau disebut juga pertimbangan hukum adalah pertimbangan hakim yang didasarkan pada fakta yang terungkap di persidangan yang merupakan konklusi komulatif dari keterangan para saksi, keterangan terdakwa dan barang bukti dan oleh undang-undang telah ditetapkan sebagai hal yang harus dimuat di dalam putusan.

Adapun Pertimbangan hakim dalam putusan No. 07/PID-SusAnak/2017/Pn.Pdg yang bersifat yuridis yaitu:

\section{a) Telah terbuktinya Dakwaan Dari Jaksa Penuntut Umum}

Dakwaan merupakan dasar hukum acara pidana karena berdasar itulah pemeriksaan di persidangan dilakukan. Dakwaan selain berisikan identitas terdakwa, juga memuat uraian tindak pidana yang didakwakan dengan menyebut waktu dan tempat tindak pidana itu dilakukan. Dakwaan yang dijadikan pertimbangan hakim adalah dakwaan yang telah dibacakan di depan sidang pengadilan. Dalam pekara No. 07/PIDSus-Anak/2017/Pn.Pdg, Penuntut Umum mendakwa Anak Fauzan Arsi Putra pgl. Ojan bin Abadi dengan bentuk dakwaan Alternatif Subsidaritas yaitu :

\author{
Dakwaan Kesatu : \\ Primair : \\ Pasal 351 ayat (2) KUHP jo Undang- \\ undang Nomor 11 tahun 2012 tentang \\ Sistem Peradilan Pidana Anak. \\ Subsidiair :
}

Pasal 351 ayat (1) KUHP jo Undangundang Nomor 11 tahun 2012 tentang Sistem Peradilan Pidana Anak.

\section{ATAU :}

Dakwaan Kedua :

Pasal $76 \mathrm{C}$ jo. Pasal 80 Undangundang Nomor 35 tahun 2014 tentang Perubahan atas Undang-undang Nomor 23 tahun 2002 tentang Perlindungan Anak jo Undangundang Nomor 11 tahun 2012 tentang Sistem Peradilan Pidana Anak.

Sesuai dengan fakta-fakta yang terungkap dihadapan persidangan maka Penuntut Umum berkeyakinan bahwa Dakwaan Kesatu Primair yang terbukti. Dimana Penuntut Umum menuntut anak Fauzan Arsi Putra pgl. Ojan bin Abadi telah terbukti secara sah dan meyakinkan bersalah melakukan "Tindak Pidana Penganiayaan yang mengakibatkan luka berat" sebagaimana diatur dan diancam pidana melanggar pasal 351 ayat (2) KUHP jo Undang-undang Nomor 11 tahun 2012 tentang Sistem Peradilan Pidana Anak dan menuntut supaya anak Fauzan Arsi Putra pgl. Ojan bin Abadi dipidana penjara selama 1 (satu) tahun dan 6 (enam) bulan di Lembaga Pembinaan Khusus Anak (LPKA) Tanjung Pati Kabupaten 50 Kota.

\section{b) Keterangan Saksi}

Sebelum memberikan putusan pidana Hakim Anak mempertimbangkan keterangan saksi korban, dimana akibat tindakan pelaku Anak telah 
mengakibatkan timbulnya trauma, cedera fisik berupa rusaknya bola mata (cacat) dan psikis (depresi atau rasa takut). Kepercayaan diri korban menurut karena ada cacat di wajah, dan hal ini didukung oleh keterangan saksi-saksi lain yang dihadirkan oleh Penuntut Umum yang dihadirkan di persidangan.

Dalam menyidangkan Anak sebagai pelaku pidana, Hakim juga memperhatikan ketentuan dari pasal 60 Undang-undang Nomor 11 tahun 2012 tentang Sistem Peradilan Pidana Anak (UU Sistem Peradilan Pidana Anak):

\section{Pasal 60}

(1) Sebelum menjatuhkan putusan, Hakim memberikan kesempatan kepada orang tua/Wali dan/atau pendamping untuk mengemukakan hal yang bermanfaat bagi Anak.

(2) Dalam hal tertentu Anak Korban diberi kesempatan oleh Hakim untuk menyampaikan pendapat tentang perkara yang bersangkutan.

Keterangan dari orang tua Anak dihadirkan di persidangan karena anak dibawah umur masih menjadi tanggung jawab dari orang tua Anak, untuk mengetahui kebiasaan keseharian orang tua bersama Anak, sehingga dari keterangan orang tua anak, Hakim bisa memperoleh informasi nantinya yang dijadikan pertimbangan bagi hakim dalam memutus perkara tindak pidana yang dilakukan oleh Anak. Dimana Hakim Anak juga akan menilai keadaan orang tua anak yang menjadi bagian dari latar belakang Anak, karena dari beberapa kasus anak sebagai pelaku tindak pidana sering kali dijumpai bahwa anak sebagai pelaku tindak pidana tidak mendapatkan kasih sayang dan perhatian yang cukup dari orang tuanya yang disebabkan oleh beberapa faktor dimana yang paling sering yaitu faktor ekonomi orang tua yang tidak memungkinkan dalam mendidik anak dimana kedua orang tua anak harus bekerja seharian di luar untuk memcukupi kebutuhan ekonomi sehingga pendidikan anak terbengkalai.

\section{c) Keterangan Anak Pelaku}

Menurut Pasal 184 butir e KUHAP, keterangan terdakwa digolongkan sebagai alat bukti. Keterangan terdakwa adalah apa yang dinyatakan terdakwa di sidang tentang perbuatan yang ia lakukan atau yang ia ketahui sendiri atau dialami sendiri. Dalam praktik persidangan, keterangan terdakwa dapat berbentuk pengakuan ataupun penolakan dari terdakwa, baik sebagian ataupun keseluruhan terhadap dakwaan penuntut umum dan keterangan yang disampaikan oleh para saksi. Keterangan terdakwa sekaligus juga merupakan jawaban atas pertanyaan hakim, penuntut umum ataupun dari penasihat hukum. Dalam pekara No. 07/PID-SusAnak/2017/Pn.Pdg, Anak Fauzan Arsi Putra pgl. Ojan bin Abadi mengakui perbuatan telah melakukan penganiayaan.

\section{d) Barang Bukti}

Pengertian barang bukti di sini adalah semua benda yang dapat dikenakan penyitaan dan diajukan oleh penuntut umum di depan sidang pengadilan, yang meliputi: 
Dewi Elvi Susanti: Pemidanaan Terhadap Anak Sebagai Pelaku Tindak Pidana...

(1)Benda atau tagihan tersangka atau terdakwa seluruhnya atau sebagian diduga diperoleh dari tindak pidana atau sebagai hasil tindak pidana;

(2)Benda yang dipergunakan secara langsung untuk melakukan tindak pidana atau untuk mempersiapkan;

(3)Benda yang digunakan untuk menghalang-halangi penyidikan tindak pidana;

(4)Benda lain yang mempunyai hubungan langsung dengan tindak pidana yang dilakukan.

Barang-barang bukti yang dimaksud di atas tidak termasuk alat bukti. Hal ini dikarenakan Undang-Undang yaitu Kitab Undang-undang Hukum Acara Pidana pasal 184 KUHAP menetapkan lima macam alat bukti yaitu keterangan saksi, keterangan ahli, surat, petunjuk, dan keterangan terdakwa. Sementara itu barang bukti yang dihadirkan di persidangan memiliki nila tambah bagi keyakinan hakim dalam menilai benar tidaknya perbuatan yang didakwakan kepada terdakwa, sehingga hakim akan lebih yakin jika barang bukti itu dikenal dan diakui oleh terdakwa ataupun saksisaksi. Adapun barang bukti dalam pekara No. 07/PID-Sus-Anak/2017/Pn.Pdg, terdakwa Anak Fauzan Arsi Putra pgl. Ojan bin Abadi, adalah: gear besi sepeda motor, sabuk karate, sepeda motor, pakaian korban.

\section{e) Terpenuhinya \\ Tindak Pidana}

Unsur-Unsur

Dalam membuktikan dakwaan yang didakwakan kepada Anak penuntut umum dan hakim berusaha untuk membuktikan dakwaannya melalui alat-alat bukti tentang apakah perbuatan terdakwa telah atau tidak memenuhi unsur-unsur yang dirumuskan dalam pasal peraturan hukum pidana. Apabila berdasarkan fakta-fakta yang terungkap dipersidangan ternyata perbuatan terdakwa memenuhi unsurunsur dari setiap pasal yang didakwakan berarti terbuktilah menurut hukum kesalahan terdakwa, yakni telah melakukan perbuatan seperti diatur dalam pasal yang didakwakan kepadanya. Melalui unsur-unsur dari pasal yang didakwakan terhadap Anak, hakim mempertimbangkan apakah Anak telah memenuhi seluruh atau sebagian unsur dari tindak pidana yang dilakukan oleh Anak dengan memperhatikan alat bukti yang ditentukan pasal 184 KUHAP, alat bukti yang sah terdiri dari keterangan saksi, keterangan ahli, surat, petunjuk, keterangan terdakwa, dari 5 (lima) alat bukti tersebut harus ada minimal 2 (dua) alat bukti yang diajukan ke persidangan. Berdasarkan proses pembuktian di persidangan Hakim Anak menyatakan bahwa dakwaan Primair yaitu pasal 351 ayat (2) KUHP terlah terbukti semua unsur-unsurnya.

\section{f) Hal-Hal Yang Memberatkan}

Sebelum menjatuhakan pidana terhadap Anak, Hakim Anak memperhatikan hal-hal yang memberatkan dan meringankan Anak, dimana pertimbangan ini dibentuk hakim Anak untuk mewujudkan suatu keadilan bagi Anak sebagai Pelaku Kejahatan, anak sebagai korban kejahatan dan masyarakat. Dalam perkara ini hal yang memberatkan adalah tindakan Anak 
Pelaku yang telah membuat cedera fisik korban yang terlihat dari hasil Visum Et Repertum Nomor: Y.M.01.08.1.5.1261 tanggal 22 Juni 2016 dengan kesimpulan: pada pemeriksaan korban seorang lakilaki yang menurut Surat Permintaan Visu et Repertum berumur enam belas tahun, ditemukan luka-luka terbuka pada daerah kelopak mata kiri atas, pipi kiri, mermar pada pipi kiri dan beberapa luka lecet pada daerah bibir serta pendarahan di bilik depan mata kiri, lumpuhnya syaraf yang mengatur pupil serta kecurigaan adanya pendarahan di dalam cairan rongga mata kiri akibat kekerasan tumpul, cedera tersebut telah menimbulkan berkurangnya fungsi penglihatan mata kiri. Disamping itu, tindakan anak selaku pelaku kejahatan telah meresahkan masyarakat.

\section{g) Hal-Hal Yang Meringankan}

Sikap baik Anak Pelaku selama di persidangan dan tAnak Pelaku yang belum pernah dihukum sebelumnya merupakan hal-hal yang meringankan yang menjadi pertimbangan Hakim Anak sebelum menjatuhkan Pidana terhadap Anak Pelaku. Dalam kasus ini Hakim juga mempertimbangkan ada atau tidak perdamaian antara Anak Pelaku dan Anak korban, meskipun perdamaian tidak menghapus tindak pidana namun dapat menjadi dasar bagi hakim untuk memberikan keringanan hukuman terhadap terdakwa.

Demikian umur Anak Pelaku menjadi pertimbangan bagi hakim dalam mengadili dan memutus perkara Anak, karena umur anak menjadi pertimbangan bagi hakim dalam menentukan bentuk sanksi pidana yang akan dijatuhkan kepada Anak, karena ancaman pidana Anak sebagai pelaku tindak adalah 1/2 (satu per dua) dari maksimum ancaman pidana penjara yang diancamkan terhadap orang dewasa dan terhadap Anak tidak berlaku ancaman minimal khusus pasal 79 ayat (2) dan ayat (3) Undang-undang Nomor 11 tahun 2012 tentang Sistem Peradilan Pidana.

\section{h) Memperhatikan Hasil Penelitian Kemasyarakatan}

Berdasarkan pada Pasal 60 ayat (2) dan ayat (3) UU Sistem Peradilan Pidana Anak menyatakan:

Pasal 60 UU Sistem Peradilan Pidana Anak

(3) Hakim wajib mempertimbangkan laporan penelitian kemasyarakatan dari Pembimbing Kemasyarakatan sebelum menjatuhkan putusan perkara.

(4) Dalam hal laporan penelitian kemasyarakatan sebagaimana dimaksud pada ayat (3) tidak dipertimbangkan dalam putusan Hakim, putusan batal demi hukum.

Mempertimbangkan hasil Laporan Penelitian Kemasyarakatan (Litmas) yang dibuat oleh Balai Pemasyarakatan (BAPAS), yang meliputi:

i) Faktor intern yakni dalam diri Anak sebagai pelaku tindak pidana, misalnya kejiwaan dari Anak apakah memang memiliki dasar sifat atau kepribadian yang tidak baik yang nantinya apabila membaur dengan kehidupan sosial masyarakat akan lebih 
Dewi Elvi Susanti: Pemidanaan Terhadap Anak Sebagai Pelaku Tindak Pidana...

merugikan dari pada manfaat yang di peroleh dari masyarakat sehingga si Anak sebagai pelaku tindak pidana harus dipisahkan dari masyarakat agar mendapatkan perhatian, pembinaan pengawasan dan pendidikan yang lebih intensif untuk diarahkan agar menjadi pribadi yang lebih baik;

ii) Faktor ekstern yakni pengaruh dari luar yang mempengaruhi Anak sebagai pelaku tindak pidana yang diperoleh dari lingkungan, keluarga, pergaulan dan pendidikan serta efek yang ditimbulkan akibat perbuatan Anak sebagai pelaku tindak pidana bagi korban, masyarakat, orang tua dan lingkungan.

\section{i) Keyakinan Hakim}

Keyakinan hakim menjadi dasar pertimbangan dalam menjatuhkan sanksi pidana bagi Anak, keyakinan ini dibangun dari fakta-fakta yang terungkap di persidangan, jika hakim tidak yakin atau ada keragu-raguan dari suatu tindak pidana yang dilakukan oleh Anak maka hakim dapat menjatuhkan putuan bebas.

\section{2) Pertimbangan Non Yuridis}

Pertimbangan non yuridis tersebut antara lain adalah aspek sosiologis, psikologis, kriminologis dimana ketiga aspek tersebut merupakan aspek yang saling terkait yang membantu hakim untuk menganalisa secara obyektif dan realistis (Madhe Sadhi Astuti, 2003 :43), sehingga pemahaman mengenai aspekaspek non yuridis dalam hubungan dengan tindak pidana anak di samping sangat relevan, juga menjadi penting bagi seorang hakim ketika ia menangani perkara tentang pidana anak, sehingga putusannya akan menjadi lebih adil dan tepat. Aspek sosiologis berguna untuk mengkaji latar belakang sosial mengapa seorang anak melakukan suatu tindak pidana, aspek psikologis berguna untuk mengkaji kondisi psikologis anak pada saat anak melakukan suatu tindak pidana dan setelah menjalani pidana sedangkan aspek kriminologi diperlukan untuk mengkaji sebab-sebab seorang anak melakukan tindak pidana dan bagaimana sikap serta prilaku anak yang melakukan tindak pidana, dengan demikian hakim diharapkan dapat memberikan putusan yang adil sesuai dengan kebutuhn anak (Madhe Sadhi Astuti, 2003: 47).

Pertimbangan sosiologis yang dipakai oleh hakim dalam memberikan putusan adalah kondisi sosial keluarga yang tidak harmonis, sehingga kontrol keluarga terhadap perilaku terdakwa berkurang. Kemudian anak bergaul dengan lingkungan sosial yang penuh dengan kekerasan.

Adapun pertimbangan psikologis yang dipakai oleh hakim dalam memutus perkara a quo adalah sifat-sifat emosional anak masih belum stabil serta masih belum dapat membedakan perbuatan mana yang baik dan yang buruk oleh karena itu perlu ditangani secara khusus dalam rangka memberikan perlindungan dan kesejahteraan anak. Salah satu aspek yang terkait dalam peranan hakim dalam peradilan pidana adalah terkait dengan jenis-jenis pidana yang dapat dijatuhkan kepada anak, untuk itu hakim dalam memutus perkara pidana anak perlu mengetahui faktor-faktor yang melatar 
belakanginya termasuk masa lalu si anak, sehingga dalam hal ini hakim harus benarbenar bijaksana dalam bertindak untuk itu dibutuhkan pengetahuan yang luas dan mendalam bagi seorang hakim agar putusan yang dijatuhkan dapat mecerminkan keadilan, terhindar dari kesewenang-wenangan dan sesuai dengan kebutuhan anak.

Terkait putusan Hakim tersebut, penulis menilai putusan yang dijatuhkan terhadap Anak Fauzan Arsi Putra pgl. Ojan bin Abadi dihubungkan dengan teori tujuan pemidanaan dalam hukum pidana, telah dengan cermat dan teliti serta bijaksana dalam menjatuhkan putusan dengan pidana penjara selama 1 (satu) tahun di Lembaga Pembinaan Khusus Anak (LPKA) Tanjung Pati Kabupaten 50 Kota. Dihubungkan dengan teori tujuan pemidanaan antara lain Teori Absolut, dimana tindakan pembalasan didalam penjatuhan pidana ditujukan bahwa penjatuhan sanksi pidana terhadap anak pelaku tindak pidana bertujuan supaya anak pelaku tindak pidana menyadari bahwa perbuatan yang dilakukan melanggar hukum yang berlaku, sedangkan menurut teori relatif yang pada prinsipnya teori ini menghendaki untuk mencari dasar hukum pidana dalam menyelenggarakan tertib masyarakat dan akibatnya, yaitu dengan tujuan preventif terjadinya kejahatan, dihubungkan dengan putusan Hakim Anak terhadap Anak Fauzan Arsi Putra pgl. Ojan bin Abadi, bahwa tujuan pemidanaan terhadap anak Fauzan Arsi Putra pgl. Ojan bin Abadi tersebut untuk menakut-nakuti atau memperingatkan kepada anak pelaku, dengan demikian anak pelaku akan jera dan tidak mengulangi perbuatannya lagi. Sedangkan menurut teori gabungan yang merupakan perpaduan antara teori absolut dan teori relatif penulis menilai bahwa putusan Hakim tersebut telah bijaksana dimana Hakin telah mempertimbangkan hal yang meringankan dan memberatkan yang diselaraskan dengan tujuan pemidanaan yaitu terciptanya keadilan baik bagi korban maupun bagi Anak Pelaku.

\section{SIMPULAN}

1. Tuntutan yang diajukan oleh Penuntut Umum terhadap anak yang melakukan tindak pidana dengan mengajukan tuntutan yang sifatnya memberi efek jera kepada anak sebagai pelaku tindak pidana, namun Penuntut Umum tetap memikirkan keunikan anak dalam posisinya sebagai pelaku tindak pidana, dimana Penuntut Umum memikirkan dan mempertimbangkan keadaan anak yang masih membutuhkan pendidikan demi masa depan anak sebagai generasi penerus bangsa namun tetap memikirkan keadilan bagi korban walaupun mungkin dari perspektif korban dan kelurganya keaadilan yang diupayakan oleh Penuntut umum jauh dari harapan.

2. Putusan Hakim Anak dalam menjatuhkan pidana terhadap Anak yang melakukan tindak pidana didasari dengan beberapa pertimbangan dan memperhatikan kepentingan Anak, yaitu: 
Dewi Elvi Susanti: Pemidanaan Terhadap Anak Sebagai Pelaku Tindak Pidana...

a. Berapa kali Anak tersebut melakukan tindak pidana lebih dari satu kali.

b. Perbuatan Anak tersebut melakukan suatu tindak pidana apakah tergolong dalam kejahatan berat mengakibatkan dampak yang serius.

c. Apakah Anak tersebut sudah tidak dapat diperbaiki lagi dengan upaya lainnya.

d. Apakah Anak tersebut membahayakan masyarakat.

Penjatuhan pidana penjara terhadap Anak menimbulkan dampak negatif dan kerugian khususnya terhadap terpidana anak, diantaranya yaitu:

a. Anak akan akan terpisah dari keluarganya

b. Anak menjadi lebih ahli tentang kejahatan.

c. Anak tersebut diberi cap oleh masyarakat

d. Masyarakat menolak kehadiran mantan terpidana Anak sehingga masa depan Anak menjadi lebih suram.

Namun faktanya yang terjadi, anak yang telah dijatuhi pidana penjara mereka justru tidak menjadi lebih baik dari sebelumnya tetapi justru akan melakukan kembali tindak pidana, maka dari sini dapat dikatakan bahwa ternyata penjatuhan pidana penjara tidaklah efektif dalam upaya menanggulangi kejahatan yang terjadi tetapi justru menimbulkan dampak-dampak yang merugikan bagi anak.

3. Dengan diberlakukannya Undangundang Nomor 11 tahun 2012 tentang Sistem Peradilan Pidana Anak yang bertujuan agar terwujud peradilan yang benar-benar menjamin perlindungan kepentingan terhadap Anak yang berhadapan dengan hukum, dimana Undang-undang Nomor 11 tahun 2012 tentang Sistem Peradilan Pidana Anak mengatur secara tegas tentang Keadilan Restoratif yang merupakan suatu proses yang melibatkan semua pihak untuk mengatasi masalah serta menciptakan suatu kewajiban untuk membuat segala sesuatunya menjadi lebih baik dengan melibatkan korban, anak dan masyarakat dalam mencari solusi untuk memperbaiki, rekonsiliasi dan menentramkan hati yang tidak berdasarkan pembalasan.

\section{UCAPAN TERIMA KASIH}

Ucapan terimakasih diberikan kepada:

1. Prof. Dr. Elwi Danil, SH, MH;

2. Yoeserwan, $\mathrm{SH}, \mathrm{MH}$,

Selaku Dosen Pembimbing yang selalu memberikan bimbingan, arahan dan masukan sehingga penulis dapat menyelesaikan penelitian ini yang telah membantu penulis dalam menyelesaikan penelitian ini "Pemidanaan Terhadap Anak sebagai Pelaku Tindak Pidana di Wilayah Hukum Pengadilan Negeri Padang, dalam perkara Nomor: 07/Pid.Sus-Anak/2017/Pn.Pdg. 


\section{DAFTAR PUSTAKA}

\section{Buku-buku:}

Deni Setyo Bagus Yuherawan, 2009, Dekontruksi Azas Legalitas Hukum Pidana, Setara Press, Surabaya.

Harkristuti Harkrisnowo, Tantangan dan Agenda Hak-Hak Anak, Jakarta, Newsletter Komisi Hukum Nasional, Edisi Februari 2002

Mukti Arto, 2004, Praktek Perkara Perdata pada Pengadilan Agama, Pustaka Pelajar, Yogyakarta.

Muladi, 1995, Kapita Selekta Sistem Peradilan Pidana, Badan Penerbit Universitas Diponegoro, Semarang.

M. Nasir Djamil, 2015, (Pimpinan Panja Sistem Peradilan Pidana Anak Komisi III DPR RI), Anak Bukan untuk Dihukum, Sinar Grafika,

Maidin Gultom, 2014, Perlindungan Hukum terhadap Anak, Refka Aditama.

Zainal Abidin, 2005, Pemidanaan, Pidana dan Tindakan Dalam Rancangan KUHP, Position Paper Advokasi RUU KUHP seri 3, ELSAM, Jakarta.

\section{Jurnal:}

Wiwik Afifah, Pertanggung Jawaban Pidana Anak Konfilik Hukum, Vol
10, No. 19, Hal 48-62, Februari 2015.

Olvina Kartika Mamentu, Peran Pasal 2 Undang-undang Nomor 11 tahun 2012 tentang Sistem Peradilan Pidana Anak terhadap Anak yang berkonflik Hukum, Lex Crimen Vol IV/No.2/April/2015

Adi Hardiyanto Wicaksono, Pujiyono, Kebijaksanaan Pelasanaan Diversi sebagai Perlindungan Bagi Anak yang Berkonflik Hukum pada tingkat Penuntutan di Kejaksaan Negeri Kudus, 2015, Jurnal Law Reform, Volume 11, Nomor 1. 2015.

\section{Peraturan Perundang-undangan:}

Undang-Undang Republik Indonesia Nomor: 35 tahun 2014 tentang Perubahan atas Undang-undang Nomor 23 tahun 2002 tentang Perlindungan Anak (LNRI tahun 2014 Nomor 297)

Undang-Undang Republik Indonesia Nomor 11 tahun 2012 tentang Sistem Peradilan Pidana Anak. 